\title{
O IBGE e a geografia quantitativa brasileira:
}

\section{Construindo um objeto imaginário}

The IBGE and the brazilian quantitative geography: building an imaginary object

El IBGE y la geografía cuantitativa brasileña: la construcción de un objeto imaginario

L'IBGE et la géographie quantitative brésilienne : la construction d'un objet imaginaire

\section{Mariana Lamego}

\section{(2) OpenEdition}

\section{Journals}

Edição electrónica

URL: https://journals.openedition.org/terrabrasilis/1015

DOI: 10.4000/terrabrasilis. 1015

ISSN: 2316-7793

Editora

Rede Brasileira de História da Geografia e Geografia Histórica

Refêrencia eletrónica

Mariana Lamego, «O IBGE e a geografia quantitativa brasileira:», Terra Brasilis [Online], 3 | 2014, posto online no dia 30 junho 2014, consultado o 05 dezembro 2022. URL: http://journals.openedition.org/ terrabrasilis/1015 ; DOI: https://doi.org/10.4000/terrabrasilis.1015

Este documento foi criado de forma automática no dia 5 dezembro 2022.

All rights reserved 


\title{
O IBGE e a geografia quantitativa brasileira:
}

\author{
Construindo um objeto imaginário \\ The IBGE and the brazilian quantitative geography: building an imaginary \\ object \\ El IBGE y la geografía cuantitativa brasileña: la construcción de un objeto \\ imaginario \\ L'IBGE et la géographie quantitative brésilienne : la construction d'un objet \\ imaginaire
}

Mariana Lamego

\section{Introdução: IBGE e geografia quantitativa}

1 Nos dias de hoje, possivelmente para alguns geógrafos e para muitos estudantes de geografia, a relação com o IBGE se dá por meio de sua página na rede internacional de computadores na qual estão disponíveis infinitos dados, índices, gráficos, estatísticas, enfim, toda sorte de informações sobre a população, sociedade e economia do país, nas esferas federal, estadual e municipal. Sua missão institucional, conforme exposta na rede, é a de "retratar o Brasil com informações necessárias ao conhecimento da sua realidade e ao exercício da cidadania".

2 Ainda que pese certo exagero, não é inadequado sugerir que a importância do IBGE hoje para a geografia é por demais reduzida, restringindo-o a uma confiável fonte de dados. Não se reconhece mais, atualmente, o IBGE como um centro produtor de conhecimento geográfico, em pé de igualdade com as universidades. A relação IBGE e geografia sofreu alguns abalos de metade do século XX para os dias de hoje.

3 Mas não foi sempre assim. Por isso o tom de tristeza e bastante nostalgia nos textos escritos por figuras 'históricas' do instituto ${ }^{1}$ - como os geógrafos Orlando Valverde, Speridião Faissol, Fany Davidovich, Roberto Lobato Corrêa, entre outros - a respeito do 
período áureo do IBGE, que se estenderia entre as décadas de 50 e fins da década de 70 . São com saudade lembrados os sempre árduos trabalhos de campo, que colocavam os pesquisadores na aridez do sertão, no deserto do centro-oeste, na vastidão dos pampas. Muitos são os relatos sobre longas caravanas em lombo de cavalo, boléias de caminhão, ou mesmo a pé, seguindo líderes atrás de algum santo graal geográfico (que poderia ser, quem sabe, um novo distrito federal). Canseira recompensada pela sensação, expressa de modo quase unânime, de que estavam fazendo a geografia do país. Sobre a vivência no 'gabinete', entre pares, derramam elogios à competência dos ibgeanos, à qualidade de sua produção e ao empenho nas pesquisas. Não se furtam de, quando lhes convém, tecer comentários sobre um ou outro, com quem a dificuldade em trabalhar gerou distanciamentos e, por vezes, antipatias. Falam das 'patotas', das parcerias, dos grupos de afins, das amizades e inimizades.

4 Acima de tudo, tais relatos expressam a crença que tinham os ibgeanos de que o que faziam era fundamental para o país. Viveram um período em que se questionou pouco, ou mesmo não se questionou, a insistente celeuma sobre a relevância social da geografia. Até mesmo porque, como sugere Neil Smith, a idéia de relevância social está em constante modificação, entrelaçada que é à conjuntura $(1989$, p. 8). E, naquela época, pensavam os geógrafos que, para ser socialmente relevante, precisava a geografia contribuir ativamente para o conhecimento científico em prol do desenvolvimento social e econômico do país. E era o quê se propunham.

Nas décadas de 60 e 70, o IBGE despontou como um dos núcleos difusores da geografia quantitativa brasileira, junto ao Núcleo de Rio Claro, formado por professores da UNESP, como Antonio Christofoletti e Alexandre Filizola Diniz. A geografia quantitativa que se difunde no IBGE possuiu sua identidade costurada à história desta instituição, que por sua vez, conecta-se à história do país. Em poucas palavras, se em Rio Claro, certas circunstâncias bastante peculiares permitiram que o grupo do interior paulista gozasse de uma autonomia considerável na gestão de seus projetos, no IBGE a história foi diferente. O IBGE não é uma escola de formação de geógrafos. Ao se elaborar tal afirmação, é preciso deixar claro que não se ignora o fundamental papel jogado pelo órgão na formação dos geógrafos brasileiros, especialmente em momento no qual as instituições acadêmicas se consolidavam como espaço de produção do conhecimento. No entanto, tal afirmação pretende chamar a atenção para o fato de ser o IBGE um órgão vinculado à esfera da política nacional, e é nesse sentido que precisa ser compreendida tanto a influência de diferentes escolas do pensamento geográfico quanto a própria incorporação da geografia quantitativa na prática dos pesquisadores objeto de interesse desse trabalho.

6 Por conseguinte, antes de abordar a rica história da geografia quantitativa ibgeana, cabe ressaltar a existência de uma articulação entre a história do IBGE e a história política brasileira. Para caracterizar a geografia quantitativa no IBGE é necessário, portanto, conhecer a história desta instituição. Por sua vez, para construir a história do IBGE é necessário conhecer a história política do país. É somente recorrendo ao desenrolar dos episódios que misturam diversas camadas contextuais - política nacional e política ibgeana - que é possível perceber a natureza da geografia desenvolvida no IBGE e sua vinculação aos componentes das políticas do Estado e, mais importante, compreender como se deu o desenvolvimento de uma versão quantitativa da disciplina. ${ }^{2}$

7 Tal consideração revela-se crucial para entendimento de como no IBGE as ditas escolas do pensamento geográfico, ou mesmo as tradições geográficas, foram assimiladas, 
adulteradas e recontextualizadas em contingências históricas constitutivas. Como se daí se derivasse uma história do pensamento geográfico ibgeana, na qual percebe-se, muitas vezes, a coexistência, ou mesmo a hibridização, de matrizes e suas versões específicas numa dinâmica bastante peculiar e particular. Acredito ser somente por meio de uma análise que articule as componentes sociais e epistêmicas da geografia quantitativa que se evita sucumbir no vício/erro de tratar a história da geografia brasileira como um amontoado de episódios auto-referenciados e auto-explicativos.

Isso posto, este artigo se divide em quatro seções. Na primeira procura-se desenhar o panorama da chegada da chamada revolução quantitativa no Brasil, destacando os episódios, personagens e fatos que marcaram a introdução de técnicas até então inéditas na prática dos geógrafos ibgeanos. Na segunda seção, a intenção é demonstrar como diferentes 'escolas' do pensamento geográfico coexistiram no IBGE, e isso inclui a versão quantitativa da disciplina no período aqui proposto de 1969 a 1978, e para tal faz-se uma análise da produção propriamente dita dos geógrafos que embarcaram no quantitativismo difundido na Revista Brasileira de Geografia. Na terceira seção são apresentadas reflexões feitas pelos principais personagens dessa história que manifestaram seu posicionamento a respeito da adoção, difusão e crítica da geografia quantitativa brasileira no período de declínio do quantitativismo.

9 Vale dizer, ainda, que o objetivo maior desse artigo, além de compartilhar parte de um interessante e revelador capítulo da história da geografia brasileira, é demonstrar a inexistência de uma suposta hegemonia da geografia quantitativa nas pesquisas e produções científicas do IBGE no período que se estende entre 1969 e 1978.

\section{Geografia quantitativa no IBGE: um começo de uma história}

1969, Rio de Janeiro, RJ.

Após longas horas num avião, desembarca na Ilha do Governador, o geógrafo britânico John P. Cole. Era esperado pelo amigo Speridião Faissol que lhe ofereceu sua casa, onde Cole ficou hospedado pelos seguintes três meses. Aquela era sua segunda visita ao país, a segunda visita ao IBGE, finalmente equipado com os computadores que poderiam rodar as análises fatoriais que antes, precisavam ser enviadas de Nottingham. Os dois amigos trabalhavam durante todo o dia e à noite, após o jantar, ficavam horas às voltas com a teoria dos jogos.

10 Diversos elementos convergiram para tornar o ano de 1969 crucial para o desenvolvimento da geografia quantitativa ibgeana. A aproximação com a geografia anglo-americana por meio da visita de geógrafos estrangeiros, a grande mudança administrativa, mudanças nos cargos de chefia, ascensão de novos grupos são alguns desses elementos cujos desdobramentos possibilitaram a adoção e a difusão da geografia quantitativa no IBGE.

11 Naquele período, entre 1967 e 1969, o IBGE recebeu três visitas muito importantes. Os geógrafos John P. Cole, Brian Berry e John Friedman chegaram com uma valiosa bagagem: livros, manuais, programas de computador para tratamento de dados e a ambição para difundir seus conhecimentos em relação a nova geografia praticada nos mundos de língua inglesa. É interessante notar que essas três visitas propiciaram um envolvimento extenso com a geografia quantitativa, do ponto de vista teórico, metodológico e prático. John Peter Cole contribuiu para o aprendizado das técnicas geografia quantitativas. O geógrafo era já uma grande referência por conta do livro 
Quantitative Geography (Cole e King, 1966) - verdadeira bíblia da geografia quantitativa entre os geógrafos brasileiros; Brian Berry que conectava desenvolvimento, planejamento, teoria e técnicas - em inúmeros artigos que havia publicado até aquele período sobre sistemas urbanos e planejamento; e Friedmann que se destacava como um dos grandes teóricos do desenvolvimento com a teoria centro-periferia.

O geógrafo inglês John P. Cole teria vindo ao Brasil pela primeira vez em 1968, por conta de uma bolsa que ganhou do governo britânico para estudar o sistema urbano brasileiro (Almeida, 2000, p. 98). Veio, travou contatos, e voltou no ano seguinte com malas cheias. Em 1969, John P. Cole auxiliou os geógrafos do IBGE na introdução de técnicas quantitativas, como métodos de análise fatorial e agrupamento, método Cadeia de Markov, entre outros (Reis Jr., 2003, p. 53).

As circunstâncias da visita de Berry e Friedmann, por sua vez, surgem narradas no depoimento que Faissol concedeu a Almeida (1995, p. 176). Segundo Faissol, foi por acaso que Berry e Friedmann foram parar no IBGE. Inicialmente, os dois geógrafos eram esperados por Harry Cole, à época diretor do SERFHAU (Serviço Federal de Habitação e Urbanismo), para uma consultoria de uma grande pesquisa desenvolvida por aquela agência. No entanto, na véspera da chegada dos visitantes, Harry Cole foi demitido do SERFHAU. Atônito, teria ligado para o amigo Faissol solicitando-lhe que recepcionasse Berry e Friedmann. Faissol aceitou a oferta e levou os dois para o IBGE onde ministraram cursos sobre as técnicas quantitativas. Cabe aqui o relato da curiosa conversa que Faissol teria travado com Harry Cole às vésperas da chegada dos visitantes:

Então o Cole [o Harry e não o John P.] me telefona e diz: "Eu tenho o Brian Berry e o

Friedmann que vêm ao Brasil passar duas semanas e eu estou fora do SERFHAU.

Você quer ficar com eles?" Eu falei: “É para já." (Faissol em Almeida, 1995, p, 176).

Naquelas duas semanas que passaram entre os geógrafos do IBGE - já devidamente introduzidos nas técnicas quantitativas por John P. Cole que viera antes - Berry e Friedmann não apenas aprofundaram os ensinamentos sobre técnicas e métodos quantitativos como demonstraram possibilidades de uso para o caso da realidade nacional - análise fatorial, dimensional e de agrupamento nos estudos de cidades; cadeia de Markov para estudos de hierarquia, rede urbana, estudo de áreas metropolitanas e projeções populacionais; método Intervenning Opportunity para análises de fluxo de mercadorias, para citar alguns exemplos de aplicação. Segundo Faissol, as técnicas aprendidas com Friedmann e Berry possibilitaram a substituição daquelas utilizadas anteriormente nas pesquisas (como por exemplo, as de Perroux). Sobre a visita, comenta Faissol:

Quando o John Friedmann veio e o Brain Berry começou a mostrar claramente, muitas técnicas foram desenvolvidas naquela estatística para os geógrafos. Eram métodos de definir, métodos de grau de polarização, tinha todo um conjunto, uma parafernália técnica para fazer isso (Faissol em entrevista a Almeida, 1995, p. 177).

Como resultado, os laços entre a geografia quantitativa brasileira e a geografia quantitativa norte-americana pareceram mais atados que nunca. Muitos livros foram trazidos pelos dois visitantes, que foram lidos, traduzidos e difundidos dentro do IBGE entre aqueles que se interessavam pela geografia quantitativa.

Quando chegaram ao IBGE, Cole, Berry e Friedmann encontraram um ambiente fértil para fincar as raízes da geografia quantitativa. Todavia, para que tal ambiente estivesse 
pronto para os voluntariosos visitantes, convergiram outros tantos elementos que serão apresentados a seguir.

Um importante elemento diz respeito aos interlocutores que os visitantes encontrariam por aqui. Especialmente porque, no que diz respeito aos métodos quantitativos, era necessário que se contasse com profissionais realmente interessados e dispostos a enfrentar a árdua tarefa de (re)aprender matemática.

Sobre esta questão, que de forma alguma pode ser negligenciada, reside significativa parcela da celeuma que gerou a geografia quantitativa desde os primeiros contatos travados. De um grande contingente de geógrafos atuando no IBGE, muito poucos, especialmente nesse momento inicial, encararam o desafio de entender as técnicas quantitativas, tão logo perceberam sua complexidade. E não por acaso, se tornaram verdadeiros confrades.

19 Geiger (1997), no artigo que escreveu para a revista Geosul - inspirado possivelmente pelo tom confessional presente nas recollections escritas por velhos geógrafos quantitativos americanos e ingleses - relata como foi o primeiro contato travado com a geografia quantitativa, quando teve em suas mãos o trabalho de Brian Berry, Essays on Commodity Flows and the Spatial Structure of the Indian Economy, ${ }^{3}$ escrito em 1966:

$\mathrm{O}$ início [do texto] me atraiu muito, mas eis que se segue a Análise Fatorial, e não entendi mais nada. Pela primeira vez, me vi diante de um texto, dito de Geografia, que não adiantava reler, que continuava sem entender nada (Geiger, 1997, p. 134).

O comentário cômico de Geiger, revela um aspecto muito importante acerca da chegada da literatura quantitativa nas mãos dos ibgeanos. Tratava-se de uma linguagem muito diferente da empregada usualmente nos trabalhos desenvolvidos pela geografia da época. A começar por se tratar de textos escritos em inglês - e, considerando a influência francesa na geografia brasileira, a fluência no inglês não era tão comum quanto no francês; ${ }^{4}$ some-se a esse aspecto o aparecimento, em tais textos, de uma sofisticada linguagem matemática ainda alienígena nos trabalhos da geografia nacional - pois não era como a matemática desenvolvida na estatística, esta sim já velha conhecida.

21 A reação à matemática é uma questão crucial se quisermos entender o processo de difusão da geografia quantitativa no Brasil, e, entender boa parte de suas críticas. Isso porque adotar a geografia quantitativa incluía entender e dominar suas técnicas. Entendimento e domínio, por sua vez, dependiam de tomar lições naquela nova linguagem nas horas vagas. Além disso, incluía a posse de certa habilidade que não poucos geógrafos simplesmente não tinham ou recusaram-se a desenvolver. Talvez por isso se possa afirmar que ser um geógrafo quantitativo no IBGE, naquele final da década de 60, significava, para muitos, um avanço no que eram consideradas certas deficiências na própria formação profissional tradicional.

Visitantes voluntariosos e anfitriões acolhedores são dois elementos que já convergem, mas não são o bastante. Era preciso um ambiente favorável, no qual aquela novidade significaria um aprimoramento, ou como acreditavam os confrades, um verdadeiro progresso das pesquisas desenvolvidas pela geografia do IBGE. Além isso, era preciso que tal aprimoramento fosse consensual, em outras palavras era preciso que muitos reconhecessem que a geografia quantitativa representava o novo norte a ser seguido. De nada adiantava um e outro ibgeano desejarem utilizar técnicas quantitativas em suas pesquisas, porque foram os únicos a se dar conta dos benefícios que elas traziam. Especialmente em se tratando de um órgão público cujas pesquisas estavam atreladas a 
uma agenda oficial. Era preciso que aquela novidade se tornasse ela mesma oficializada, pois isso seria garantia de sua sobrevivência e desenvolvimento. Ainda mais por se tratar de uma novidade bastante exigente, do ponto de vista operacional, dependente que era do robustecimento do aparato tecnológico do IBGE e exigente também do ponto de vista intelectual, uma vez que um grande empenho era necessário para sua apreensão.

Por conseguinte, para que tal ambiente se realizasse realmente era preciso pôr em operação um importante instrumento constitutivo do universo sociológico do fazer ciência: a persuasão. $O$ poder de convencer e de arregimentar um crescente número de signatários, sendo esta a estratégia que garantiria o avanço da geografia quantitativa. No entanto, em um espaço de coexistência de muitas visões distintas sobre a disciplina, tal estratégia encontrava alguns obstáculos que precisavam ser superados estreitamente conectados ao jogo das relações e conflitos profissionais. Sobre isto, diz Latour que

quando nos dirigimos da vida 'cotidiana' para a atividade científica, do homem comum para o da ciência, dos políticos para os especialistas, não nos dirigimos do barulho para o silêncio, da paixão para a razão, do calor para o frio. Vamos de controvérsias para mais controvérsias. (...) Na verdade, o barulho é maior, e não menor (Latour, 2000, p. 53).

Naquele IBGE de fins da década de 60, o 'barulho' envolvia duas importantes figuras, cujas histórias na instituição são merecedoras de atenção: Lysia Bernardes e Speridião Faissol. Lysia Bernardes e Faissol podem ser considerados líderes de círculos de afinidade dentro do IBGE, seriam, também, herdeiros de um 'barulho' pretérito, envolvendo o 'grupo' do Macedo e o 'grupo' do Zarur. ${ }^{5}$ Lysia e Faissol alternaram-se nos postos de alto poder do IBGE, numa gangorra que segundo Almeida (2000, p. 144) perdurou de 1956 a 1968.

Durante a década de 60 , é tida como incontestável a liderança exercida por Lysia Bernardes no papel de coordenadora das pesquisas desenvolvidas na Divisão de Geografia. Lysia vinha sistematicamente se dedicando à área de geografia urbana, desde o início da década de 60, quando deixou para trás sua antiga área de atuação: a climatologia (Almeida, 2000, p. 127). Sua aproximação com o geógrafo Michel Rochefort se dá nessa época. Rochefort foi um dos muitos geógrafos franceses que visitaram o IBGE muitas e muitas vezes para prestar consultorias ao órgão. Seu método de estudos sobre redes de cidade, com ênfase na análise do setor terciário (Almeida, 2000, p. 122) foi amplamente adotado nas pesquisas empreendidas pelo IBGE, sendo eleito o mais adequado às pesquisas desenvolvidas naquele período, e Lysia Bernardes contribuiu de modo significativo para sua difusão.

A partir de 1964, intensificaram-se as pesquisas sobre as redes urbanas e os estudos sobre o processo de regionalização, seguindo ainda o modelo de Rochefort. Essas pesquisas contavam com a participação massiva do quadro de geógrafos humanos do IBGE. Comenta Almeida (2000, p. 29) que nenhum pesquisador, que não fosse do IBGE, teria tanto conhecimento sobre a estrutura urbana e regional do país. Consequiência dessa reconhecida qualidade seria a solicitação feita ao IBGE pelo Ministério do Planejamento para que o instituto produzisse uma análise da estrutura urbana brasileira para que se determinassem os pólos de desenvolvimento para fins de planejamento durante o regime militar. 
27 Naquela época vivia a geografia do IBGE certo estado de latência, tendo em vista a relativa perda de importância uma vez experimentada durante a fase inicial de suas atividades, quando o instituto atuou de modo mais decisivo na concretização da política do Estado Novo de Vargas. Voltar a uma posição de destaque no sistema de planejamento do Estado - não mais como um mero fornecedor de índices, mas como um instituto de pesquisa produtor de análises - era desejo de muitos geógrafos que viveram aquela época. ${ }^{6}$ Todavia não estava o IBGE sozinho nesta empreitada, dividiu os méritos com o recém-criado Escritório de Pesquisa e Economia Aplicada (EPEA, posteriormene IPEA), instituído em 1966 (Almeida, 2000, p. 49), com o qual foi firmado convênio para cumprir a agenda do Ministério do Planejamento. Como principais frutos de tal convênio destacam-se os documentos Subsídios à Regionalização (1968) e Regiões Funcionais Urbanas (1970) (Almeida, 2000, p. 43).

28 A partir de 1967, dois episódios vão movimentar a gangorra de Lysia Bernardes e Faissol. Em 1967, por conta de um projeto de reforma do Estado, o IBGE deixa de ser uma autarquia para se tornar Fundação, decomposta em órgãos autônomos, o Instituto Brasileiro de Estatística (IBE), o Instituto Brasileiro de Geografia (IBG) e a Escola Nacional de Ciências Estatísticas (ENCE). A antiga Divisão de Geografia do IBGE é substituída pelo Departamento de Geografia (DEGEO) do IBG. Na qualidade de Fundação, o IBGE passa a gozar de autonomia administrativa e financeira, ligando-se diretamente ao Ministério do Planejamento e Coordenação Econômica.

29 Um ano depois da mudança administrativa, em 1968, como conseqüência das boas relações que travou Lysia Bernardes com o IPEA, a geógrafa deixa a chefia da Divisão de Geografia do IBGE para dar início a sua carreira como planejadora daquela agência do governo federal. Com a vacância do cargo ocupado por Lysia Bernardes, entra em cena a figura ainda discreta de Marília Veloso Galvão, dileta seguidora de Faissol, que vai ocupar o cargo de chefe do então criado Departamento de Geografia em sua mais longa gestão, de 1968 a 1979.

30 A saída de Lysia Bernardes da cena do IBGE torna Faissol o novo coordenador das pesquisas, da qual participaram Roberto Lobato Corrêa, Pedro Pinchas Geiger, Fany Davidovich, Marília Velloso Galvão. Naquele ano de 1969, Faissol cria o Grupo de Áreas Metropolitanas (GAM) e dá início a sua cruzada quantitativista no IBGE.

31 Com esse episódio, finalmente convergem os elementos que fizeram do DEGEO do IBGE um ambiente pronto para o desenvolvimento da geografia quantitativa.

32 O GAM de Faissol não fazia parte da estrutura formal do instituto. Sendo assim, a escolha de seus componentes era de inteira responsabilidade de seu coordenador. Nesse sentido, o GAM pode ser entendido como um verdadeiro laboratório de Faissol, para testar as possibilidades das técnicas quantitativas e ganhar crescente notoriedade dentro e fora do instituto. Faissol arregimentou uma equipe (curiosamente composta apenas por mulheres) que tivesse algum domínio de matemática, tomou a frente na interlocução com geógrafos quantitativos visitantes e iniciou uma série de estudos para aplicação das técnicas e modelos matemáticos na pesquisa sobre regiões metropolitanas.

Sobre o GAM de Faissol, algo de suas características permite uma aproximação com o segundo circuito de Latour (1999, p. 100), denominado autonomização. Segundo Latour, a autonomização diz respeito à "maneira na qual uma disciplina, uma profissão, uma sociedade secreta, ou um 'colegiado invisível', tornam-se independentes e formam seus 
próprios critérios e avaliação e relevância" (Latour, 1999, p. 102, tradução da autora). 0 GAM sem dúvida alguma, durante sua existência, gozou de uma autonomia institucional e independência de ação que propiciou o desenvolvimento da geografia quantitativa no IBGE e fez deslanchar a carreira de Faissol.

Assinando como GAM ou sozinho, Faissol publicou dezenas de artigos na RBG, e alguns livros sob a chancela do IBGE. Em sua grande maioria, tratou de falar das técnicas quantitativas. Por isso mesmo, conhecer a geografia quantitativa ibgeana depende, sobremaneira, em conhecer a obra de Faissol. Melhor, conhecer a obra de Faissol é conhecer a geografia quantitativa ibgeana. Assim como Christofoletti em Rio Claro, Faissol exerceu com bastante propriedade a posição de líder, em versão dupla: como 'guru' intelectual e como coordenador do grupo de pesquisas de geografia quantitativa mais ativo e como primeiro superintendente de pesquisas do IBGE.

Apesar do reconhecido protagonismo, Faissol não foi o único geógrafo do IBGE a se interessar e aplicar as técnicas quantitativas. Destacam-se as figuras de Pedro Geiger, Fany Davidovich, Roberto Lobato Corrêa, Marília Velloso Galvão, Olga Maria Buarque de Lima e Elza Keller, entre outros. Cada um desses imprimiu suas características decorrentes de seus temas de estudo, suas visões da disciplina, seus gostos e desgostos e forneceu à geografia quantitativa ibgeana o tanto de suas peculiaridades.

Todos os geógrafos listados já faziam parte do quadro do IBGE há pelo menos 10 anos quando aportaram as novidades. Estavam à frente de pesquisas importantes, participavam ativamente da Associação de Geógrafos Brasileiros (AGB), ministravam cursos de aperfeiçoamento nas mais diferentes temáticas, eram convidados para ministrar aulas em diversas instituições, já haviam passado por alguma experiência de intercâmbio, enfim, compunham uma classe bastante eminente e valorizada no círculo social do quadro profissional do IBGE e também do quadro acadêmico da geografia. Eram, muitos deles, jovens em idade e maduros na profissão. Por isso, sem maiores arroubos, experimentaram a novidade quantitativa. Contavam com um apoio operacional que nenhuma outra instituição poderia conceder. Se na primeira visita de Cole precisaram usar a máquina do setor de informática da PUC, ${ }^{7}$ já em sua segunda visita, Cole encontrou o IBGE devidamente equipado para a realização de análise fatorial e de agrupamento.

Como dito anteriormente, tal ambiente não nasceu de um dia para outro. E tampouco, depois de surgido, estava para sempre garantido. A persuasão foi uma estratégia utilizada não somente uma vez, mas todo o tempo. Especialmente porque a geografia quantitativa no IBGE acabou se configurando em um número pequeno de pesquisadores, extremamente produtivos, porém pouco numerosos. Nessa estratégia de persuasão para que se forjassem as alianças - o terceiro circuito de Latour $(1999$, p. 100) - jogou a RBG papel crucial.

\section{Uma caixa aberta - o que queriam, o que diziam, e o que fizeram os ibgeanos?}

Uma das teses que defendo é que não é possível afirmar ter havido hegemonia da geografia quantitativa no IBGE. Evidências para essa afirmação podem ser obtidas quando se toma como base o principal veículo de divulgação das pesquisas elaboradas pelos geógrafos pertencentes ao instituto, a Revista Brasileira de Geografia (RBG). Convém 
lembrar a dupla natureza das pesquisas realizadas no instituto: (1) as que eram resultantes de 'encomendas oficiais' e (2) as que não eram:

1. As oficiais atendiam às demandas das políticas do Estado, via Ministério do Planejamento ou mesmo por meio de convênios travados com outros institutos, como o IPEA (Instituto de Pesquisa Econômica Aplicada), secretarias como o SERFHAU (Serviço Federal de Habitação e Urbanismo) ou então superintendências, como SUDENE (Superintendência do Desenvolvimento do Nordeste) e SUDAM (Superintendência do Desenvolvimento da Amazônia). Tratam-se de estudos solicitados pela direção do IBGE ao seu quadro funcional, "pressupondo-se geralmente um entendimento prévio da metodologia a ser aplicada e da forma final do produto" (Almeida, 2000, p. 26).

2. As não-oficiais eram pesquisas desenvolvidas pelos geógrafos do IBGE, a partir de motivações particulares, conectadas por exemplo à formação do geógrafo, ou a interesses seus em relação a temas ou abordagens da geografia, "podendo estar relacionadas ou não às linhas de pesquisa do órgão" (Almeida, 2000, p. 26).

39 Convém ressaltar que muitas vezes há convergências entre pesquisas oficiais e não oficiais. Em outras palavras, os geógrafos do IBGE eventualmente aprofundaram pesquisas próprias a partir do envolvimento em trabalhos oficiais. Da mesma forma que imprimiram em trabalhos oficiais muito de suas formações pessoais e visões da disciplina construídas durante investigações em pesquisas não oficiais. Isso posto, é importante observar que nem sempre podemos depreender do texto propriamente dito se trata de uma pesquisa oficial ou não-oficial.

O que se percebe é o fato de que essa convergência se faz evidente nas páginas da RBG. Espaço de difusão por excelência da vasta produção geográfica do IBGE, a RBG é composta tanto por trabalhos oficiais quanto por trabalhos dos geógrafos do IBGE. Há que se ressaltar que nesses mais de sessenta anos de publicações, a linha editorial da RBG sempre foi muito eclética. O ecletismo da RBG nada mais é que reflexo do ecletismo da geografia do IBGE.

41 A RBG teve seu primeiro número publicado no ano de 1939 (um após a criação do instituto) e seu último número foi publicado em $2005 .{ }^{8}$ Cada volume da RBG consiste de quatro números, isto é, são quatro edições por ano, excetuando-se nove anos em que tal periodicidade não se observou. ${ }^{9}$

42 Considerou-se, na investigação que realizei, o ano de 1969 como aquele em que os primeiros sinais da chegada das técnicas quantitativas se fizeram sentir na RBG, e o ano de 1978 como aquele no qual foi perceptível o enfraquecimento desta abordagem nas pesquisas desenvolvidas pelos seus geógrafos.

43 Na pesquisa fiz uma extensa exposição e análise das evidências que sustentam a tese segundo a qual não houve uma hegemonia da geografia quantitativa no IBGE. Julgo importante ressaltar o sentido que se dá aqui a ideia de hegemonia. Por hegemonia entende-se o predomínio de uma visão da disciplina sobre outra. O problema que tive em mãos, portanto, era o de estabelecer uma maneira de avaliar o predomínio ou não da geografia quantitativa no IBGE no período de 1969-1978. Foram utilizados dois critérios: (i) o número de artigos de geografia quantitativa em relação ao total de artigos publicados na RBG no período; (ii) a ocorrência contínua de artigos expressamente tributários da geografia quantitativa.

Em tais análises foram tecidos comentários sobre os mais ilustrativos trabalhos, devidamente referenciados. O objetivo foi reconhecer algumas passagens que 
expressavam a natureza da adoção e aplicação das técnicas quantitativas nos trabalhos oficiais e nos trabalhos dos geógrafos do IBGE, chamando atenção para a linguagem utilizada e para as temáticas privilegiadas. Cabe ressaltar que também foram selecionados para comentários artigos de pesquisas que não expressavam a adesão à geografia quantitativa. A idéia era demonstrar a coexistência de diferentes tendências teóricas e metodológicas na produção do IBGE durante o período de 1969-1978.

As etapas concernentes à análise da produção da geografia quantitativa do IBGE não se ativeram a uma fórmula rígida. Tendo como modelo uma interessante fórmula desenvolvida por Reis Jr. (2007), procurou-se em primeiras leituras algum tipo de identificação e grifo de linguagens empregadas com visível freqüência, a identificação das principais categorias de análise utilizadas, as referências bibliográficas ou, ainda, os autores citados que foram reconhecidos como elementos que contribuiriam como indícios para uma ou outra filiação teórica.

Um segundo momento foi a análise propriamente dita do texto, procurando salientar os objetivos (quando apresentados), a natureza da pesquisa (quando foi possível inferir) e os resultados encontrados (quando expostos). Nesse ponto, utilizou-se o recurso da reconstrução, que não poderia ser mais que uma aproximação, do que teria sido o pensamento do autor. Nesta etapa são incorporadas as ferramentas para a análise dos argumentos que o autor utiliza para defender sua posição.

Uma dificuldade encontrada durante essa fase da pesquisa demonstra mais um interessante traço da geografia quantitativa ibgeana. Alguns artigos permitiram uma identificação bastante clara e rápida da filiação teórica, isto é, ou eram quantitativos ou não eram. Especialmente aqueles escritos pelos geógrafos mais destacados do movimento, por exemplo Speridião Faissol, Roberto Lobato Corrêa, Fany Davidovich ou Marília Velloso Galvão. Ou por aqueles que não aderiram à geografia quantitativa $\mathrm{e}$ seguiram fazendo pesquisas numa linha filiada à tradição da geografia francesa.

Porém, houve artigos em que tal filiação não se mostrava tão evidente. Ainda que se reconhecessem algumas técnicas, não se reconheciam conceitos, referências, ou mesmo uma linguagem apropriada pertencente ao rol da geografia quantitativa. $\mathrm{O}$ uso disseminado de estatísticas, expostas em forma de tabelas extensas ou gráficos - que figurou como uma das marcas das pesquisas de geografia feitas no IBGE a partir da década de 50, resultado de um grande empenho em sistematização da produção do instituto - acabou contribuindo para gerar certa confusão. Ou seja, não bastava que o artigo estivesse recheado de tabelas com índices e gráficos para classificá-lo como um exemplar da geografia quantitativa. Até mesmo porque, diversos economistas e estatísticos expuseram suas pesquisas nas páginas da RBG e seguiam tendências outras que aquelas adotadas pelos geógrafos quantitativos.

O que realmente qualifica um trabalho como filiado à geografia quantitativa são as referências bibliográficas utilizadas, bem como os conceitos postos em uso. Ainda são traços da adoção da geografia quantitativa a exposição de modelos matemáticos ou a elaboração de análises mais refinadas com os dados estatísticos, como a análise fatorial e análise de agrupamento.

51 Todavia, com o aumento no número de artigos que seguiam obscuros, ou de muito difícil identificação, esse empecilho passou a ser interpretado como um interessante aspecto da geografia quantitativa ibgeana. $O$ uso freqüente de técnicas quantitativas sem a devida adoção da metodologia e das bases teóricas revelou-se mais comum que o esperado. $\mathrm{O}$ que permitiu inferir que, a partir de determinado ponto houve gradações 
no que tange à adoção da geografia quantitativa pelos geógrafos do IBGE, especialmente entre aqueles que poderiam ser considerados pertencentes a uma segunda geração (em sua grande maioria discípulos de Faissol). Cabe ressaltar que, a partir de meados da década de 70, alguns geógrafos de fora do IBGE também começaram usar as técnicas quantitativas. Tal fato, ao mesmo tempo em que indica o papel do IBGE como disseminador das técnicas quantitativas, por outro lado aponta que essa disseminação se deu de forma híbrida, alguns geógrafos assumiram o projeto como um todo, já outros adotaram a geografia quantitativa de forma bastante superficial. Teria ocorrido, então, certo distanciamento dos próprios alegados clamores da geografia quantitativa, qual seja, uma sofisticação no plano teórico resultante do uso adequado de técnicas quantitativas.

52 Cabe, finalmente, uma importante ressalva. Em momento algum se pretendeu, nas leituras feitas dessa produção, elaborar qualquer análise de natureza 'psicologizante' que especulasse sobre o que tal autor pretendeu dizer quando redigiu seu texto. Defendo a existência do hiato entre o contexto de produção e o contexto de apropriação. Acredito, na necessária autonomia que ganha o texto escrito, sendo esta a condição que o torna um proveitoso objeto de análise. É claro que todas as informações que se somam sobre o autor, incluídas aí sua trajetória de vida - ou o que dela se tornou público - seu tempo e seu lugar, estão de algum modo presentes e operantes, quando previamente conhecidas, durante a análise de seu texto.

Em função da finalidade e característica do presente artigo, não cabe uma exposição tão detalhada dos sumários das edições da RBG de 1969 a 1978, tampouco dos 42 artigos selecionados e analisados em minha investigação. A seguir serão apresentados, a título de ilustração, alguns dos principais artigos do período selecionado que permitem a construção de uma narrativa sobre a adoção e tradução da geografia quantitativa no IBGE.

\section{A representatividade da geografia quantitativa na $\mathrm{RBG}$ - 1969 a 1978}

O ano de 1969 é o ano da adoção das técnicas quantitativas por alguns geógrafos do IBGE, não é o ano, porém, do início de uma produção ibgeana marcadamente quantitativa. Esta precisou de um tempo maior de gestação de pelo menos um ano, para que fosse iniciada a produção dos textos que seriam publicados pela RBG. O que se nota são ainda tímidas referências a alguns geógrafos quantitativos, especialmente Brian Berry e sugestões de uma agenda de pesquisa futura.

Os textos analisados neste volume de 1969 são de autoria de quatro dos mais ativos geógrafos do IBGE que produziram trabalhos afinados à metodologia quantitativa, nos anos seguintes: Pedro Geiger, Roberto Lobato Corrêa, Fany Davidovich e Faissol e seu grupo.

Os artigos são ilustrativos de um período em que ainda se praticava uma geografia com ênfase no tema das regiões e do espaço urbano - cuja influência da geografia francesa (corporificada em Michel Rochefort) é notável. São também representativos de um modo de fazer geografia no IBGE que foi perdendo espaço (sem jamais desaparecer!) na produção geográfica do IBGE, baseado em extensos trabalhos de campo e tratamento sistemático de grandes volumes de dados empíricos. 

menção a teoria dos pólos de desenvolvimento deixa ver que o Grupo de Faissol cumpriu toda essa primeira etapa com base em Perroux. ${ }^{14}$ No entanto, os autores enfatizam certas mudanças no plano do método que se desejava colocar em prática na 
segunda etapa da pesquisa. De fato, é somente a partir do próximo ano que o GAM avança na adoção das técnicas quantitativas apresentadas por Cole, Berry e Friedman, no estudo sobre as regiões metropolitanas.

1970 é um ano de muitas realizações para a geografia quantitativa ibgeana. Da primeira a última edição da RBG deste ano a geografia quantitativa se faz presente. E na última edição, particularmente, se faz unânime - feito que não iria realizar novamente. Como exposto no editorial do n.4 de 1970, tratava-se de um número especial, tendo em vista a atenção do IBGE estar voltada para a utilização das técnicas quantitativas qualificadas como as

armas com que contam os geógrafos do Brasil para atender ao desafio que lhes apresenta, ao adotarem as modernas técnicas que a geografia vem absorvendo de outros ramos do conhecimento (RBG, 1970, pp. 3-4).

É válido conjecturar sobre as possíveis causas dessa exclusividade de artigos quantitativos em uma revista que vai se caracterizar por seu ecletismo na política editorial. Poderia ser decorrência do fim do período de gestação, mencionado anteriormente, das primeiras pesquisas fazendo uso de técnicas quantitativas, ou ainda dos estudos sobre os textos estrangeiros sobre a tendência quantitativista nas geografias inglesa e norte-americana. Considerando que aqueles que se deixaram conquistar pela geografia quantitativa iniciaram as pesquisas utilizando técnicas quantitativas na mesma época, é natural pensar que os primeiros trabalhos tenham surgido na mesma época também. Outra razão decorreria do fato de, em 1970, o grupo de Faissol estar bastante fortalecido politicamente dentro do IBGE - tendo Marília Velloso Galvão à frente do DEGEO desde 1968 (onde ficou até 1977, uma das chefias mais longas da história daquele departamento, diga-se). Tal centralização de poder do grupo de Faissol seria, então, determinante na editoração desse número. Outra causa se relacionaria ao investimento nas técnicas quantitativas por parte dos principais geógrafos vinculados às pesquisas sobre a rede urbana, tema privilegiado pelo IBGE nesse período. ${ }^{15}$

O artigo "Renovação na Geografia"16 é o primeiro a aparecer na RBG falando de geografia quantitativa, residindo nesse caráter precursor parte de seu valor. É eminentemente teórico e apresenta o processo de renovação metodológica pelo qual vinha passando a disciplina. Publicado na seção 'Comentários' o artigo conta com apenas cinco páginas, e inicia abordando a posição da geografia em meio às ciências, defendendo a necessidade de desenvolver métodos eficazes na predição dos fenômenos geográficos. Como é possível perceber no excerto a seguir:

(...) de acordo com o processo geral das ciências sociais, hoje em dia não se trata apenas de estudar os fatos geográficos na sua evolução até o presente, mas de indicar as tendências espontâneas do movimento para o futuro, bem como apontar as possibilidades de intervenção no processo econômico, no sentido de encontrar situações espaciais mais desejáveis (Geiger, 1970, p. 64).

Há muito do posicionamento de Geiger em relação a geografia nesse excerto. Certamente Geiger não foi o único a apontar os possíveis benefícios que decorreriam da aplicação das técnicas quantitativas nas pesquisas geográficas que lidavam com grande quantidade de dados a manipular (essa foi, inclusive, a mais mencionada vantagem dessas técnicas). Entretanto, Geiger é mais enfático que muitos ao apontar sempre na direção de uma conexão permanente da geografia com os problemas sociais, apontar para sua relevância como uma ciência social capaz de, se não solucionar, ao menos fornecer caminhos para soluções dos problemas decorrentes de um desenvolvimento 
econômico desigual. Foi nesse sentido que sustentou sua adoção às técnicas quantitativas. E talvez em função desse laço - relacionado mais à aplicabilidade efetiva do quantitativismo que o seu significado como possível avanço epistemológico - Geiger pode transitar pelas muitas abordagens e teorias que alimentaram as pesquisas da geografia ibgeana. Sua trajetória, em termos de produção, reflete que Geiger 'entrou e saiu' da geografia quantitativa sem maiores dramas, do mesmo modo que 'entrou e saiu' da geografia regional e da geografia sistemática, influência direta que teve o geógrafo alemão Leo Waibel, muito importante na história do IBGE nos anos 40 e $50 .{ }^{17}$

Geiger segue no artigo apresentando algumas das vantagens do uso do aparato quantitativo. Insiste na idéia de ser tal aparato apenas um das etapas da metodologia quantitativas, sendo a construção de modelos um dos principais objetivos da aplicação das técnicas - aqui se percebe o alinhamento de Geiger ao argumento central na defesa da adoção das técnicas quantitativas utilizado pelos geógrafos norte-americanos. Neste artigo não há uma introdução minuciosa das técnicas, o que poderia revelar talvez uma estratégia para não assustar os incautos, ou então falta de mais páginas para tal apresentação. Ainda assim, há espaço para uma breve apresentação da Teoria Geral dos Sistemas e sua relação com os métodos quantitativos.

O número 4 da RBG de 1970 merece destaque. Pode ser considerado, sem sombra de dúvidas, o emblemático número da geografia quantitativa ibgeana. São ao todo seis artigos publicados, todos exclusivamente dedicados à geografia quantitativa. Esse número cumpre efetivamente o papel de introduzir a geografia quantitativa em relação às seus objetivos e metodologias. Cabe ressaltar que no ano seguinte de sua publicação, estes seis artigos foram traduzidos e reunidos em um livro intitulado Quantitative Geography in Brazil que o IBGE lançou como "comunicação exterior" (Reis Jr., 2003, p. 53). Pode-se afirmar que este é o número emblemático da geografia quantitativa brasileira. A seguir são apresentados alguns dos artigos mais expressivos desse número.

O primeiro artigo "A revolução quantitativa na Geografia e seus reflexos no Brasil”, assinado por Faissol e Marília Velloso Galvão tornou-se, como o de Geiger comentado acima, uma importante referência nos estudos sobre a geografia quantitativa no Brasil. Bem mais extenso que o de Geiger (característica usual dos artigos de Faissol, diga-se), neste artigo já são sugeridos, como explicita o título, os primeiros desdobramentos da adoção do quantitativismo na geografia brasileira. Chama atenção a escolha do termo 'revolução', que indicaria a adesão de Faissol à corrente de geógrafos que consideraram que tal revolução de fato aconteceu, corroborando a idéia, que ao termo subjaz, segundo a qual transformações de amplo espectro teriam acontecido.

o que se percebe na análise de tal artigo, e que se tornará um elemento bastante comum nos trabalhos seguintes de Faissol, é a preocupação constante que demonstra em esclarecer a nova metodologia quantitativa. Nesse artigo, em especial, por se tratar do primeiro, tal preocupação se volta à explicação dos sentidos dos termos principais, por isso, tão logo iniciam, os autores anunciam que pretendem demonstrar aqueles que seriam os pontos mais importantes acerca do desenvolvimento da geografia (e aqui, de modo transparente, seguem a cartilha da geografia quantitativa): os métodos quantitativos são o caminho para tornar a geografia uma ciência, uma vez que desenvolveriam "sua capacidade de precisar os fenômenos e estabelecer os princípios gerais, segundo os quais os mesmos ocorrem” (Faissol e Galvão, 1970, p. 5); e possuem uma natureza revolucionária uma vez que "alguns conceitos teóricos podem ser questionados ou reestabelecidos" (Faissol e Galvão, 1970, p. 5). 
73 Faissol e Galvão, após a apresentação do que foi a revolução quantitativa, utilizando especialmente o artigo de Burton (1963), se propõem a mostrar algumas técnicas quantitativas úteis aos estudos de regionalização. A análise fatorial, a teoria dos grafos e o método da cadeia de Markov foram as técnicas escolhidas pelos autores (convém lembrar que foram as primeiras que aprenderam com Cole, Berry e Friedman). Ao final, sintetizam em um parágrafo aquelas que seriam as maiores vantagens do uso dos métodos:

Os métodos quantitativos da moderna geografia resolvem não só o problema da utilização de um número considerável de características mas também aquele de dar a estas características - quando altamente correlacionadas - pesos proporcionais a sua participação na explicação total da diferenciação entre os lugares, eliminando, ao mesmo tempo, o subjetivismo em atribuir-se maior significação a uma ou outra variável e contornando a objeção de que elas constituem apenas uma parcela da realidade espacial, uma vez que praticamente todos os dados disponíveis podem ser utilizados, cobrindo, senão a totalidade, pelo menos a totalidade possível das características dos lugares estudados (Faissol e Galvão, 1970, p. 21).

Elza Keller ${ }^{18}$ assina artigo sobre os tipos de agricultura no Paraná. A autora apresenta um estudo que teve como objetivo a aplicação da análise fatorial (factor analysis) e a análise de agrupamento (cluster analysis) na classificação dos tipos de agricultura no Paraná. Keller enfatiza que se trata de uma experiência de combinação dos métodos quantitativos com os índices selecionados. A partir deste ponto, apresenta em seqüência as bases que serão utilizadas na análise fatorial (no caso os fatores são os produtos agrícolas) e os critérios que preponderaram na escolha dos índices. Após a análise fatorial, aplica-se a análise de agrupamento que estabelecerá a conexão entre os tipos de agricultura e as regiões agrícolas. O artigo termina em uma seqüência de mapas do Estado do Paraná, cada qual representado um fator. Certamente, por não fornecer maiores explicações, ou seja, por se tratar da aplicação da técnica quantitativa e da apresentação de resultados, o artigo de Keller é de difícil compreensão para aqueles não apresentados à metodologia quantitativa. Cabe ressaltar que Keller também foi uma das geógrafas do IBGE que se destacou na geografia quantitativa ibgeana, especialmente em razão de ser uma das poucas pesquisadoras do instituto a usar técnicas quantitativas no tratamento do tema de geografia agrária.

Geiger $^{19}$ vem em seguida com um estudo em que também aplicou a análise fatorial no estudo de cidades, no caso, de cidades nordestinas. A justificativa para a escolha da região aparece logo no primeiro parágrafo quando Geiger apresenta que o objetivo do artigo é

ampliar os conhecimento relativos ao fenômeno urbano do Nordeste, tendo em vista o interesse da SUDENE pelos aspectos espaciais dos processos sócioeconômicos que se desenrolam na Macroregião (Geiger, 1970, p. 131).

Um detalhe chama atenção no artigo, quando Geiger menciona que as

operações de computação, a partir da $1^{a}$ matriz composta (...) foram realizadas na Universidade de Nottingham, Inglaterra, gentileza de um de seus professores do Departamento de Geografia, nosso amigo John Cole (Geiger, 1970, 132).

De fato, nesses primeiros anos, certas operações não poderiam ser realizadas nos computadores do IBGE, sendo bastante utilizado, assim, o setor de informática da PUC.

78 No último artigo, ${ }^{20}$ retorna Faissol (publicou três somente nesse número) junto a seu mestre John P. Cole e ao geógrafo Michael McCullagh, ambos da Nottingham. $\mathrm{O}$ artigo avança sobre um tema também importante nas pesquisas do IBGE, as projeções 
demográficas e introduz o método da Cadeia de Markov como aquele mais adequado ao tratamento deste tema. Salientam os autores que o propósito do estudo é contribuir para "o conhecimento dos principais fatores que afetam o crescimento da população no Brasil e de outro lado aplicar um modelo destinado a projetar este crescimento" (Faissol, Cole e McCullagh, 1970, p. 173). Mais uma vez se faz presente o esforço de Faissol em explicar as técnicas quantitativas, no caso o funcionamento do método da Cadeia de Markov e, ainda, apontá-lo como solução para o problema relacionado às projeções feitas com os métodos comumente utilizados. Preocupado em justificar a escolha do método aponta suas vantagens, por exemplo, no planejamento do uso de recursos do país, em função da projeção ampliada que o método possibilita fazer.

1971 é um ano muito importante para a geografia quantitativa nacional. É o ano em que ocorre a Reunião da Comissão de Métodos Quantitativos da União Geográfica Internacional (UGI). A Escola Nacional de Ciências Estatísticas (ENCE) foi o espaço de realização da reunião. A participação dos ibgeanos foi intensa. Ainda nesse ano, é assinado um convênio entre o IBGE e o Ministério da Educação para avaliação do sistema de ensino superior. Nos volumes seguintes, a partir de 1972, serão apresentados resultados dessa avaliação, utilizando metodologia quantitativa. 1971 marca também o início de um período, que se estende até o final da década, de ampliação do quadro profissional do instituto (Almeida, 2000, p. 50).

Tantos episódios relevantes para o desenvolvimento da geografia quantitativa não se refletem neste volume de 1971. Curiosamente, após o emblemático n.4 de 1970, as contribuições de geografia quantitativa neste ano são muito tímidas. Em um total de dezoito trabalhos publicados, apenas quatro artigos alinham-se à metodologia quantitativa.

81 Um aspecto importante a se considerar é que, a despeito de terem sido muito produtivos, os geógrafos quantitativos do IBGE nunca foram numericamente significativos. Durante o período de vigência da geografia quantitativa ibgeana, sua produção ficou restrita a um círculo pouco extenso de pesquisadores, que precisou trabalhar dobrado para conseguir emplacar tantos artigos quanto possíveis na RBG.

Geiger, Faissol e o GAM, Roberto Lobato Corrêa, Fany Davidovich, Keller, foram aqueles que mais se envolveram em pesquisas nas quais faziam ampla utilização de técnicas quantitativas. Escoavam sua produção para a RBG nas mais diversas formas: transcrições de participações em congressos ou nos grupos de estudos internos; propostas de estudos ou reflexões acerca de métodos e técnicas, quando suas pesquisas estavam ainda em estágio embrionário; comentários bibliográficos, resultante das muitas leituras que faziam para o embasamento de suas pesquisas; e, por fim, em uma forma mais acabada, apresentavam os resultados parciais ou resultados finais. Ainda assim, os hiatos serão notáveis, o que leva a considerar também outro importante aspecto a respeito da revista. A RBG mantinha um espaço aberto à participação de outros profissionais, estatísticos, economistas, cartógrafos, geomorfólogos, em suas páginas. E também procurava, sempre que possível, expandir para a participação de profissionais de outras instituições, mormente acadêmicas. Essa é sem dúvida uma importante estratégia de difusão do conhecimento produzido e, acima de tudo, de manutenção do espaço, uma vez que a tendência é o aumento de permutas, à medida em que mais profissionais externos prestigiam a RBG.

Em 1972 acontece a Reunião da AGB em Presidente Prudente - SP. Consta que lá deu-se o primeiro grande confronto envolvendo os quantitativistas e os não quantitativistas - 
porque ainda não se poderia sugerir um grupo de críticos alinhavados em torno de uma nova perspectiva, que foi o caso da geografia crítica. Os ibgeanos e os rioclarenses compareceram em massa e apresentaram diversos trabalhos utilizando as técnicas quantitativas.

Neste ano de 1972, a RBG apresenta um peso maior na publicação de artigos de geografia quantitativa. Mais uma vez, Faissol publica bastante ao longo do ano. São seis artigos que perpassam teoria, metodologia e práticas da geografia quantitativa. Com destaque ao artigo "Teorização e Quantificação" (que será analisado a seguir), um artigo sobre a aplicação do método de trend surface analysis na determinação de polos de desenvolvimento e um comentário bibliográfico sobre Explanation Geography de Harvey (1969).

Em "Teorização e Quantificação", ${ }^{21}$ Faissol faz uma revisão dos aspectos centrais da geografia quantitativa. Trata-se de um dos principais artigos desenvolvidos pelos geógrafos quantitativos brasileiros. Logo no início, Faissol apresenta todas as vantagens que se colocariam aos geógrafos ao adotar a geografia quantitativa. $O$ caráter preditivo que ganharia a disciplina é salientado. Segundo Faissol

a utilização de técnicas quantitativas de análise de base matemática e já testadas pela estatística, está permitindo aos geógrafos não só precisar os fenômenos que analisa, de modo antes não possível por métodos convencionais, mas também e principalmente, pela capacidade que estes métodos têm de tornar possível a um técnica replicar os trabalhos de outro, de forma a tornar possível comparações, e também de descobrir e testar regularidades existentes, com seu corolário de inferências, o que vai dando à Geografia um caráter mais rigorosamente explanatório e em consequiência uma capacidade preditiva (Faissol, 1972, p. 145).

A análise matemática acabaria exigindo, como crê Faissol, uma melhor especificação do conjunto de fenômenos. Faria também com que as premissas fossem anunciadas, e não permanecessem implícitas, como estariam nos processos tradicionais de análise.

Faissol apresenta os principais conceitos e métodos que traz a análise quantitativa. Explora exemplos para o uso da Teoria do Campo, para a análise fatorial, para a trend surface analysis.

Define o modelo como o "filtro básico segundo o qual selecionamos os aspectos relevantes da realidade para análise" (Faissol, 1972, p. 157). Mesmo considerando as grandes dificuldades em poder definir todo o complexo de interações no interior de um sistema, um modelo de simulação do processo ofereceria consideráveis vantagens analíticas, não só porque pode produzir previsões válidas a curto e médio prazo, mas sobretudo porque oferece amplas possibilidades de teorização (FAISSOL, 1972, pp. 157-158).

Este artigo, escrito em 1972, vai se tornar uma verdadeira base para a produção futura do próprio Faissol. É muito comum encontrar diversos trechos que se repetem em outros artigos publicados, posteriormente, na RBG, como "Espaço, Geografia e Ciências Sociais", publicado no número 4 de 1974, ou no artigo que curiosamente ganhou o mesmo nome "Teorização e Quantificação na Geografia" (31), publicado no número 1 de 1978, ou até mesmo nos livros que publicou sob a chancela do IBGE, como Tendências atuais na geografia urbano/regional: teorização e quantificação ${ }^{22} \mathrm{em}$ 1978. Essa característica aponta a um aspecto interessante e que pode ser explorado. A auto-referência acabou sendo a grande saída para a difusão da geografia quantitativa ibgeana. Faissol não aumentou muito sua lista de referência de 1972 a 1978. Estão lá basicamente as mesmas 
obras, chamando atenção a ausência de bibliografia nacional (excetuando-se o livro por ele organizado, quando a referência nacional dos demais autores é Speridião Faissol).

A geografia quantitativa nacional não publicou o suficiente para que se criasse uma trilha de referências. Em certo sentido, não houve a consolidação de uma segunda geração de autores que tomassem para si a tarefa de perpetuar o pensamento da primeira geração via citação e referência. 0 período foi curto, o que contribuiu para que os trabalhos dos quantitativos nacionais não pudessem ser alçados a uma categoria de referência bibliográfica que os emparelhassem aos pesquisadores norte-americanos e britânicos. Especialmente se for levado em consideração que as grandes contribuições teóricas de fôlego não chegaram a ser empreendidas de modo satisfatório. E neste aspecto reside a importância e o papel dos artigos teóricos de Faissol.

O artigo "Um Paradigma para a Geografia Moderna" de Brian Berry publicado no número 3 da RBG de 1972 se trata do primeiro artigo de geografia quantitativa que trouxe uma discussão crítica em relação ao que teria sido uma adoção muito rápida das técnicas estatísticas e quantitativas na geografia. Essa adoção, que Berry vai qualificar de impensada, vai impedir que a geografia reflita sobre a natureza dinâmica dos fenômenos geográficos.

Por isso, Berry defende a adoção de um novo paradigma baseado na tomada de decisão ambiental e locacional e do planejamento. Nesse novo paradigma, aplicaria-se o método metageográfico que procura explicar o modo como o espaço está organizado a partir da consideração dos princípios que operam na percepção que tem o agente humano da realidade.

93 A teoria dos sistemas se torna peça chave nessa nova concepção proposta por Berry, além de teorias de tomadas de decisão. Para Berry, essas duas reunidas ao método metageográfico seriam o caminho para a solução de problemas antigos da geografia, como a relevância social, e para um processo intelectual mais contínuo da disciplina.

Em 1973 é organizado pela seção do Rio de Janeiro da AGB o simpósio "Renovação da Geografia". Como o nome sugere, esse encontro procurava consolidar o movimento de mudança metodológica nas pesquisas geográficas, produzindo a convergência de pesquisadores de diversas instituições. Quanto maior fosse o número de participantes, mais legítima era a idéia de que se havia operado uma mudança metodológica renovadora. A participação seguiu como na Reunião da UGI, polarizada entre os geógrafos do IBGE (Pedro Geiger, Bertha Becker e Jorge Xavier da Silva) e o grupo de Rio Claro (Felizzola Diniz e Lívia de Oliveira). Foram seis trabalhos apresentados. Presumese que por coincidência, dos seis trabalhos, apenas dois de seus autores não usaram a expressão renovação na/da geografia no título: Pedro Geiger (talvez porque caiba a seu artigo de 1969 a inspiração para o encontro) e Carlos Augusto de F. Monteiro, que nesta época já compunha o Departamento de Geografia da USP.

1973 é o ano em que Faissol atinge ao posto mais alto desde o início de sua carreira no IBGE, é escolhido para ocupar a recém-criada Superintendência de Pesquisas, que depois veio a se chamar Superintendência de Estudos Geográficos e Sócio-Econômicos (SUEGE). Uma vez superintendente, Faissol teve amplos poderes para contratações, especialmente porque na qualidade de Fundação, o ingresso no IBGE não era mais por meio de concursos. Como ele mesmo relata, nessa época teve "a liberdade de contratar algumas centenas de pessoas", com isso, acredita ter sido responsável por 'reequilibrar' o quadro profissional do IBGE, dando preferência ao ingresso de geógrafos em 
detrimento de economistas, como vinha acontecendo desde meados da década de 60 (Faissol em entrevista a Almeida, 1995, p. 180).

1973 na RBG é o ano em que se altera o cômputo dos artigos de geografia quantitativa. Pela primeira vez acontece o número de artigos de geografia quantitativa se iguala aos não quantitativos.

$\mathrm{O}$ ano de 1974 da RBG ilustra o argumento que aqui se sustenta. Em que pese a paridade de artigos de geografia quantitativa e não quantitativos no volume anterior, era de se esperar que tal padrão se repetisse, ou ao menos que houvesse entre os dois volumes aproximação. Mas o padrão não se repete e o percentual de artigos de geografia quantitativa sequer se aproxima. De um total de 16 artigos publicados em 1974, apenas 3 são representativos da geografia quantitativa. Tal quadro, numa análise superficial, poderia sugerir o início da decadência da geografia quantitativa. 0 que não é verdade, tendo em vista que, no volume seguinte, tal qual será mostrado, aumenta o número de publicações signatárias da geografia quantitativa. O que se pode inferir, então, é que na RBG seguiu-se difundida a produção do IBGE como um todo, que aponta a coexistência de diferentes abordagens e filiações teóricas e metodológicas.

O ano de 1975 seria o último de fôlego da produção da geografia quantitativa no IBGE. Faissol publica três artigos, o primeiro, assinado com Geiger e Galvão, de aplicação das técnicas quantitativas nos estudos urbanos; o segundo no qual apresenta o conceito de regiões nodais e o terceiro (analisado a seguir) em que apresenta uma discussão de natureza epistemológica.

99 Além de um quantificador, Speridião Faissol empenhou-se em favor da geografia quantitativa também em textos de natureza epistemológica, no qual explorava o arcabouço teórico-conceitual da geografia quantitativa. Procurou com isso, estabelecer sempre as relações entre a geografia - investida no quantitativismo - e as demais ciências sociais. $O$ artigo "Espaço, Geografia e Ciências Sociais" ${ }^{23}$ é um exemplo desse esforço de Faissol.

100 Trata Faissol do conceito de espaço em geografia e em ciência de um modo geral. Segundo Faissol pensar a localização geográfica das atividades humanas é preocupação encontrada não apenas na geografia, mas nas demais ciências sociais. A noção de espaço estaria então embutida em todas as disciplinas que compõem o crescente leque das ciências sociais. (Faissol, 1975, p. 6).

101 O ano de 1976 na RBG é o ano dos últimos frutos da geografia quantitativa. Ano em que aparecem novos nomes de geógrafos ligados às pesquisas que utilizam técnicas quantitativas. Tal disseminação, entretanto, vai gerar algumas traduções e adaptações, como era de se esperar quando um circuito restrito se abre. 0 que se observa é de fato uma disseminação das técnicas sem que tenha havido, necessariamente, uma adoção do projeto quantitativista. E como parece ser comum no discurso de todos os quantitativistas que assumiram a carga (e a pecha, depois), as técnicas não eram a geografia quantitativa, eram apenas instrumentos. Ou como aparece nos textos: as técnicas eram um meio e não um fim.

Um fato chama atenção neste volume da RBG. Pela primeira vez, desde 1969, Faissol não publica artigo na revista. Sua queda de produção vai se confirmar nos dois anos seguintes. Em entrevista que concedeu à GeoUerj, quando perguntado justamente sobre essa queda de produção, Faissol comenta que ela se deu em função dos muitos compromissos administrativos que lhe tomavam um tempo que antes dedicava às 
pesquisas. Em 1976, além de superintendente de pesquisas, Faissol havia sido eleito, para a vice-presidência da UGI, na América Latina. Além disso, continuava coordenando os estudos do GAM que seguia dando frutos quantitativos (Faissol, 1997, p. 89).

1977 é o ano em que Faissol torna-se Diretor Técnico do IBGE, o cargo mais alto que ocupou no órgão. O que se observa nesse ano da RBG é a diminuição do número de artigos de geografia quantitativa e o início de trabalhos que discutem os tema da desigualdade e dos problemas urbanos.

Sintoma do enfraquecimento da geografia quantitativa é ilustrado no conflito gerado entre geógrafos quantitativos e não quantitativos em relação a dois grandes projetos do IBGE. A produção da Coleção Geografia do Brasil, que foi editada em 1977 com cinco volumes, foi alvo de disputa entre os geógrafos do IBGE. Conforme relata Almeida,

[houve] pressões de parte dos quantitativistas para que os capítulos da parte humana fossem totalmente trabalhados por métodos quantitativos (...). Percebeuse, posteriormente que isto não seria viável, pois não haveria público leitor para este tipo de obra. $O$ resultado foi, obviamente uma acomodação entre os objetivos dos quantitativistas e a necessidade de dar continuidade a uma coleção que informava (...) as principais modificações espaciais por que passam alguns processos de ocupação do território brasileiro (Almeida, p.101).

Observa-se, então, que a força dos quantitativistas no IBGE, se nunca foi muito ampla, nesse momento estava menor ainda.

A RBG em 1978 já reflete o enfraquecimento da geografia quantitativa entre os geógrafos do IBGE. Passado o período de euforia e 'contaminação' das pesquisas desenvolvidas, apenas quatro artigos são de geografia quantitativa. De modo gradativo, foi o projeto quantitativista mostrando suas falhas e expondo a dificuldade de sua manutenção.

Saímos do beco sem saída do estudo de casos sem a ponte para a análise com significação estatística e/ou representatividade fenomenológica; mas continuamos tentando mapear, em uma mesma linguagem, espaço e tempo, seção transversal e longitudinal, sem teoria adequada nem método próprio. Este é um dos caminhos mais promissores para a teoria na Geografia, e certamente constituirá um dos temas do pensamento geográfico ao longo dos próximos anos (Faissol, 1978, p. 46).

É dessa forma que Faissol termina o artigo "Teorização e Quantificação na Geografia", ${ }^{24}$ curiosamente com o mesmo título daquele publicado seis anos antes, no n. 1 da RBG de 1972.

Neste artigo, Faissol procura fazer uma avaliação da adoção da geografia quantitativa, resumindo o contexto que circunscrevia a difusão das transformações metodológicas que havia se operado e seus efeitos sobre a disciplina. Acreditava que a geografia teria se descolado de uma posição tradicional para um novo campo fértil a teorização.

Em quase cinquenta páginas Faissol discute o significado da teoria, a relação que a geografia estabeleceu com outras ciências, os métodos indutivo e dedutivo, a definição do objeto científico e o problema dos modelos.

110 Fazendo ampla utilização do texto de Brian Berry "Um paradigma para a Geografia Moderna", já mencionado, Faissol apropria-se do modelo kuhniano para explicar o surgimento de um novo paradigma sistêmico que reuniria uma dialética "inortodoxa" que incorpora espaço e tempo. 
111 No tocante ao tema dos modelos, Faissol volta a mencionar o papel fundamental desses no caminho para a teorização. Entretanto já se nota, nesse artigo, a consciência de que a predição, serventia central dos modelos, dificilmente seria obtida.

112 Este artigo é bastante ilustrativo de um período de amadurecimento no que tange às possibilidades das técnicas quantitativas, se comparado ao entusiasmo do período inicial. As técnicas de análise passam a ser vistas como apenas acessórias ou coadjuvantes num processo de "melhor conhecimento do problema", reconhecendo-se que não poderiam oferecer parâmetros explicativos, não restava dúvida.

\section{Movimentos reflexivos dos ibgeanos}

O que se depreende na análise destes últimos anos da RBG apresentados, especialmente a partir de 1976, é o fato de ter se enfraquecido, muito rapidamente, a abordagem quantitativa nas pesquisas realizadas pelo IBGE.

$114 \mathrm{O}$ fato é que apesar de muito produtiva, apesar do empenho daqueles que abraçaram a 'causa' quantitativista, o número de geógrafos envolvidos sempre foi muito pequeno. Diversos tentaram, no entanto, poucos se adaptaram às técnicas quantitativas. 0 grande controle do conhecimento exercido por Faissol, somado à sua ascensão a cargos de chefia, parecem ter sido elementos que acabaram contribuindo para que a adoção da geografia quantitativa não se difundisse para muito além dos territórios do GAM. A geografia quantitativa foi deixando o IBGE de maneira bastante silenciosa. Geiger, Davidovich, Olga Maria Buarque, Roberto Lobato Corrêa, por exemplo, foram encaminhando suas pesquisas com base em outras abordagens. Apenas Faissol seguiu a vereda quantitativista, e teve fôlego para publicar um importantíssimo artigo em 1989 intitulado "A geografia quantitativa no Brasil: o que foi e como foi?".

115 Foram necessários alguns anos para que os geógrafos quantitativos do IBGE pudessem elaborar uma avaliação desta fase. Era preciso, inclusive, que lhes fossem ofertados canais para difundir tal avaliação. Em grande parte, esse canal foi aberto pela revista Geosul, publicação da Universidade Federal de Santa Catarina, que destina suas páginas finais a importantes depoimentos de geógrafos brasileiros, cujas trajetórias pessoais convergem na história do pensamento geográfico nacional.

116 Três autores foram selecionados para ilustrar o que seria o movimento reflexivo dos ibgeanos quantitativos: Pedro Geiger, Roberto Lobato Corrêa e Speridião Faissol. A escolha dos três se dá por duas razões. Em primeiro lugar, foram autores e pesquisadores muito ativos e se fizeram presentes em diversos artigos publicados na RBG no período de 69 a 78. Em segundo lugar, posteriormente escreveram artigos avaliando o período, ou mesmo concederam importantes depoimentos sobre a sua participação na geografia quantitativa ibgeana.

117 O movimento de reflexão de Pedro Pinchas Geiger (1997) acontece em um artigo sugestivamente intitulado "Notas autobiográficas e reflexões" publicado na Geosul. Nesse texto, além de expor algo sobre sua formação e suas escolhas na geografia, Geiger não se intimida e elabora também em seu relato uma autocrítica no tocante à adoção da geografia quantitativa, talvez motivado por uma necessidade de se afastar da péssima imagem que ficou da geografia quantitativa dos anos $80 \mathrm{em}$ diante. Geiger comenta que, nesse início da década de 80, se viu influenciado por Harvey quando seu rumo ${ }^{25} \mathrm{em}$ direção a uma geografia marxista se fez conhecer no Brasil. Vamos às suas palavras: 
Logo que 'entendi' a 'revolução quantitativa', percebi no íntimo o estrago que faria, não digo só na Geografia tradicional, mais do que isso, no comportamento tradicional, e que a introdução da lógica científica, que fosse a formal, conduziria à sua passagem para a lógica dialética e o marxismo. (Geiger, 1997, p. 134). 
(1) os geógrafos viam a geografia quantitativa como veículo para uma reascensão social da geografia - uma queixa que aparece no discurso de vários geógrafos da época e que se traduziria na quase idéia fixa de tornar a disciplina importante para o país e sua sociedade;

(2) entrevia-se a possibilidade de avançar, no plano do método, a partir do ponto onde parecia que a geografia de tradição francesa havia parado;

(3) o momento político do país teria operado como um facilitador, uma vez que a adoção da geografia quantitativa funcionaria como "meio de afirmação política e em função de um certo reacionarismo" (Corrêa, 1992, p. 29). 
geografia, mas todas as pesquisas sociais não-conjunturais, realizadas por sociólogos, antropólogos, economistas e estatísticos" (Corrêa, 1992, p. 38).

Como foi visto ao longo do texto, é inegável a representatividade de Faissol na geografia quantitativa ibgeana. Por isso mesmo, suas reflexões foram deixadas para este final. Sua vasta produção em e sobre a geografia quantitativa também se aplica à linha de textos de natureza reflexiva que escreveu. Foram muitos, dentre os quais, se destacam "A Geografia na década de 80: os velhos dilemas e as novas soluções", publicado no número 3 da RBG de 1987, e "A Geografia quantitativa no Brasil: como foi e o que foi?", publicado no número 4 da RBG de 1989. Além desses dois artigos que assina, duas entrevistas concedidas por Faissol (Almeida, 1995; Póvoa Neto e Rua, 1997) são muito reveladoras da posição do geógrafo em relação a geografia quantitativa - especialmente porque, ao contrário dos artigos autorais, nas entrevistas Faissol precisou lidar com questões incisivas a respeito das críticas ao quantitativismo na geografia. São trabalhos escritos no ocaso daquela que foi a fase em que Faissol mais produziu e mais notoriedade teve. Além de apontar sempre seus méritos, é inevitável perceber na avaliação que faz da geografia quantitativa a defesa de um projeto que foi inevitavelmente pessoal.

Nos artigos supracitados que publica na RBG, bastante parecidos, por sinal, não fosse o tom mais autobiográfico do segundo, Faissol avalia a geografia quantitativa a partir das críticas a ela dirigida. Tratando as críticas como controvérsias geradoras de crise, Faissol distingue quatro naturezas distintas das críticas, em relação (1) à teorização e (2) à quantificação - dirigidas às proposições e técnicas quantitativas; e em relação (3) à ideologia e (4) à relevância social - estas dirigidas às posições assumidas pelos geógrafos que adotaram a geografia quantitativa.

130 Sobre as duas primeiras controvérsias, Faissol lança mão de textos escritos pelos geógrafos quantitativos em seus momentos de avaliação. Inclusive sobre a própria crítica dirigida, Faissol utiliza os argumentos levantados pelos geógrafos radicais. Em outras palavras, Faissol acaba, nessas seções relatando um pouco da contenda que envolveu os quantitativos e os radicais no contexto norte-americano.

131 É quando se dedica às controvérsias relacionadas à ideologia e à relevância social que Faissol volta sua análise à experiência doméstica. Por isso, logo ao início Faissol avisa que pretende, com uma avaliação da geografia quantitativa, "resgatar este movimento de um certo terrorismo ideológico que, tanto no Brasil como em outros países tentou fulminar a Geografia Quantitativa" (1989, p. 22).

$\mathrm{Na}$ intenção de apontar os méritos da geografia quantitativa, procura, em primeiro lugar, desqualificar o discurso crítico, procurando apontar nele um patrulhamento às avessas, "com freqüência mais pessoal que institucional" (1989, p. 23). Tais colocações de Faissol são reincidentes. Faissol foi um dos alvos prediletos da crítica, explicitamente ou não. Essa predileção se justifica, em certa medida, pelo volume de sua produção, mas também, em parte, pela personalidade belicosa que parece ter possuído Faissol. 0 que é possível perceber no excerto a seguir, do depoimento que concedeu GeoUerj:

Também naquela ocasião [Conferência Regional da UGI em 1982] fui acusado de ter trazido somente geógrafos quantitativos, o que não foi verdadeiro. Não vou mencionar nomes porque isto já passou, mas algo que diziam e que até afetava minha seriedade profissional e administrativa eu não podia aceitar. E houve, de minha parte, algumas respostas contundente, meio radicais, mas, como se diz em Minas Gerais, "chumbo trocado não dói”, mas doía. Especialmente quando 
misturavam visão de mundo com metodologia e metodologia com deformações na formação profissional." (Póvoa Neto e Rua, 1997, p. 88; grifo meu). geografia quantitativa:

Voltando à questão dos críticos da quantitativa, eu costumo dizer que muitos deles criticavam por não saber nada a respeito. A resistência por vezes não chegava a ser nem política nem ideológica; era um problema com a matemática e a estatística, disciplinas nem sempre presentes com qualidade na formação do geógrafo (Faissol, 1997, p. 90).

(ii) Em segundo lugar, no trecho grifado "misturavam visão de mundo com metodologia e metodologia com deformações na formação profissional", percebe-se a preocupação de Faissol em deslocar a prática quantitativa da esfera pessoal, social e institucional na qual estava articulada. $\mathrm{E}$ o que se percebe na análise de textos escritos em um contexto pós-78 (ou seja, pós-AGB/Fortaleza) é o fato de Faissol deter-se muito mais nos ataques que recebeu dos críticos e que se dirigiam as suas supostas (porque nunca mencionadas) posições políticas pró-regime. Faissol acredita realmente que fazendo tal descolamento seria possível salvaguardar os aspectos positivos da geografia quantitativa.

137 A insistência em um descolamento da geografia quantitativa do seu contexto ou a defesa de uma suposta pureza metodológica quantitativa, maculada pelos mais afoitos ou menos comprometidos, foi uma estratégia de justificativa que, ao final das contas, corroborou na formação da própria caricatura. Faissol acabou fornecendo mais material para a caricatura durante seu ostracismo que durante seu período 'áureo'. 0 que se depreende da análise dos argumentos componentes da crítica da geografia quantitativa é a existência de uma verdadeira rejeição a Faissol e a sua posição 'monástica', que acabou se travestindo de rejeição a matemática.

Por exemplo, quando fala sobre a AGB de Fortaleza em 1978, Faissol $(1997$, p. 89) volta à idéia da confusão entre visão de mundo e metodologia. O que o geógrafo do IBGE argumenta faz até bastante sentido - o fato de que os defeitos da metodologia não terem sido discutidos e avaliados como tal (até mesmo porque isso exigiria conhecê-los) - mas Faissol enfraquece seu argumento ao sugerir que visão de mundo e metodologia não se misturam. Na verdade elas não apenas se misturam como são indissociáveis. Mas ainda assim, uma coisa é avaliar uma determinada metodologia, examinando suas 
características, seus métodos, seus propósitos, seus êxitos e desacertos munido do necessário conhecimento do assunto $e$ de sua visão de mundo - que imagino para Faissol deveria significar posicionamentos políticos mas também posicionamento face à disciplina. Outra coisa é avaliar uma determinada metodologia, ignorando suas características, seus métodos, seus propósitos, seus êxitos e desacertos porque sua visão de mundo (elaborada pela crítica) é diametralmente oposta (ou assim se presume). A necessidade de eximir os geógrafos quantitativos de uma possível ligação política com o regime militar motivou uma importante nota de rodapé do artigo de 1989. Nesta nota, Faissol procura, segundo suas palavras

esclarecer um ponto onde algumas das críticas mais contundentes foram feitas: a participação da Geografia no processo de planejamento a serviço de interesses de uma autocracia apoiada numa tecnocracia de economistas e geógrafos. Quem assistiu e participou das discussões sobre os planos de desenvolvimento nacional, regional, urbano e de regiões metropolitanas, pode verificar o quanto foi uma conquista para a Geografia se fazer presente e, nesse sentido, a contribuição de Pedro Geiger e Lysia Bernardes tem que ser considerada de forma particular; e um esforço enorme na defesa dos princípios de eficiência social/regional, de descontração das regiões metropolitanas para cidades médias etc. Na realidade, ali se estava praticando o comprometimento do geógrafo com problemas da Sociedade, de forma prática e participativa, o que viria a ser norma depois. Teria sido fácil se omitir, mas seria esse o caminho? Neste momento e neste contexto, a participação de Lysia e Nilo Bernardes, de Elza Keller e, sobretudo, de Pedro Geiger haviam sido decisivas, tanto na montagem do projeto de Divisões Regionais, como nas discussões com o IPEA. Neste contexto, ainda, foi montada a primeira pesquisa estatística a nível nacional, para ser usada na montagem do modelo de regióes funcionais. A experiência de Pedro Geiger e de Lysia Bernardes, tanto na montagem da pesquisa, como no contacto com os economistas espaciais do IPEA, era fundamental neste aspecto (Faissol, 1989, p. 27).

Três tópicos se depreendem da análise desse excerto, que aqui são de crucial importância. (1) A participação da geografia do IBGE no contexto do sistema de planejamento se dá via comprometimento de todo o quadro profissional de geógrafos que estavam imersos em pesquisas sobre geografia urbana e regionalização, independente de suas opções metodológicas. A insistente referência aos nomes de Geiger e Lysia Bernardes, como protagonistas nessa participação, não deixa de ser o modo que encontrou Faissol de clarificar o equívoco, diversas vezes cometido pela crítica, de associar a geografia quantitativa ao sistema de planejamento do regime militar e, depois, de modo mais direto, ao próprio regime. (2) Além disso, a participação efetiva da geografia nesse sistema de planejamento é vista como uma grande oportunidade para a disciplina, que poderia beneficiá-la garantindo uma maior visibilidade, o que poderia se refletir, entre outras coisas, em mais incentivos aos cursos de formação acadêmica. (3) Por fim, há no excerto, ainda que de modo implícito, a importante questão sobre a relevância social, pois uma vez integrada ao sistema de planejamento, a geografia seria o contraponto da visão da economia espacial, que concederia primazia a eficiência do sistema. Nesse caso, aos geógrafos caberia relativizar tal eficiência econômica em prol de uma eficiência social, que Faissol no excerto exemplifica por meio da questão da descontração das metrópoles.

140 Após muita retórica para defender sua posição, aponta Faissol aquele que seria o grande mérito da geografia quantitativa, e nesse aspecto, convergem opiniões de outros quantitativos. A geografia quantitativa teria representado uma experiência científica inédita para a geografia, ao estimular, via uma metodologia mais rigorosa, a formulação 
clara de hipóteses, objetivos e resultados de trabalho e o uso de uma linguagem menos ambígua e menos vaga. Segundo Faissol, "a Geografia nunca mais seria a mesma depois disso" (Faissol, 1997, p. 91).

O que se observa é que as reflexões que faz Faissol são de natureza distinta daquelas de Geiger e Corrêa. Isso ocorre porque nenhum outro geógrafo do IBGE adotou de modo tão irrestrito a geografia quantitativa. Pode-se até arriscar que, no caso de Faissol, houve uma verdadeira personificação da geografia quantitativa. Por parte dele e, talvez em conseqüência, por parte da crítica, Faissol se sentiu pessoalmente atingido pelas críticas, especialmente as mais mordazes, a respeito da geografia quantitativa. Por isso, na avaliação que faz do período quantitativo de sua produção, é possível perceber certo ressentimento de Faissol e certa necessidade em justificar todos os desdobramentos decorrentes da adoção da geografia quantitativa. Tamanho empenho acabou se tornando, em certa medida, em um tipo de aprisionamento, ao contrário de Geiger e Corrêa, que conseguiram sem maiores problemas se descolarem da geografia quantitativa, não porque estava ela sob fortes ataques e queriam eles se proteger, e sim porque se predispuseram a entender as deficiências que são constitutivas de todas as perspectivas, abordagens ou visões disciplinares.

\section{Palavras finais}

Com bastante freqüência, historiadores e filósofos da ciência têm a ilusão de que a especialidade da qual se ocupam sempre existiu; recuperam os conteúdos de uma variedade de textos que pertencem a épocas diversas e a terrenos heterogêneos e constroem as linhas de desenvolvimento de um objeto imaginário (Rossi, 1992, p. 7).

142 A expressividade da geografia quantitativa no IBGE deve-se sobretudo ao voluntarismo de um grupo de ibgeanos, no qual cabe destaque a Faissol. Tal grupo acreditava que o papel social da geografia tem estreito vínculo com o planejamento. Entretanto, não se pode afirmar sem mais que houve uma hegemonia da geografia quantitativa na geografia da época, especialmente no IBGE. Um dos fatos que corrobora essa afirmação é a continuidade de pesquisas em outras linhas no próprio IBGE.

É importante também ressaltar que a geografia quantitativa no Brasil jamais se configurou como um projeto acabado, pronto para ser implementado. $O$ que foi visto é que grande parte dos geógrafos que adotaram a geografia quantitativa depararam-se com as inovações por meio de uma série de episódios que muitas vezes não são interconectados - artigos seminais, visitas de estrangeiros, congressos internacionais. Ao contrário do que é sugerido por algumas críticas, não havia algo como um 'plano preconcebido', muito menos com origem externa, no qual a geografia quantitativa brasileira cumpriria um papel em um projeto de controle político ou econômico.

Os geógrafos que adotaram os métodos quantitativos não buscavam apenas sofisticações metodológicas. Tampouco se sustenta aqui a idéia de estarem propriamente insatisfeitos com as pesquisas que faziam. Além disso, praticamente todos os geógrafos envolvidos profundamente no projeto quantitativista produziram, em um momento posterior, uma reflexão na qual um dos problemas apontados teria sido não exatamente o excesso de matemática, mas sim deficiências na formação dos geógrafos brasileiros no que diz respeito à matemática. Além disso, reconhecem a inadequação de certas técnicas e tentaram corrigir tais inadequações, mas de modo algum a opção é simplesmente abandonar a reconhecida sofisticação teórica alcançada 
pela aplicação de métodos quantitativos. Em outras palavras: os problemas não implicam o abandono dos métodos, mas sim na correção e adequação dos mesmos.

Finalmente, cumpre expressar minha posição a respeito de esforços de construção de uma possível história da geografia brasileira. Por ser um expressivo capítulo na história da geografia, a geografia quantitativa permanece um atraente campo de estudo. Estudála, e, particularmente no caso da investigação que empreendi, estudar sua versão doméstica revelou-se uma tarefa que necessitou de ferramentas externas à própria disciplina. Daí a grande contribuição dos Science Studies, dos quais destacam-se a subvertida filosofia/sociologia da ciência feita por Latour (2000 e 1999), além das riquíssimas investidas por esses caminhos realizadas pelo geógrafo Trevor Barnes (2004a; 2004b; 2001a; 2001b).

o objetivo que conduziu minha investigação foi menos o de pretender resgatar uma história, como se do passado surgisse um novo sentido, como se dos nomes esquecidos, apagados ou execrados se instaurasse uma nova ordem, um novo juízo em uma nova saga que substituísse a famigerada maldição da geografia quantitativa brasileira. Talvez a construção de um objeto imaginário seja, de fato e fatalmente, a única possibilidade que tem o historiador. E talvez tenha sido isso que construí. De qualquer maneira, se expressa a geografia quantitativa brasileira em uma infinidade de registros de natureza diversa, desde trabalhos e pesquisas publicados especialmente na Revista Brasileira de Geografia e no Boletim de Geografia Teorética até a memória daqueles que nela se aventuraram. Que mais histórias se escrevam sobre ela então, a quem interessar possa.

\section{BIBLIOGRAFIA}

ALMEIDA, R.S. de. (2000) A geografia e os geógrafos do IBGE no período de 1938-1998. Tese de Doutorado. Programa de Pós-Graduação em Geografia. Instituto de Geociências, UFRJ, 714p.

(1995) Memória: Speridião Faissol. Caderno de Geociências, n.15, IBGE, pp.165-181.

BARNES, T. (2004a) A paper related to everything but more related to local things. Annals of the Association of American Geographers, 94 (2), pp.278-286.

. (2004b) Placing ideas: genius loci, heterotopia and geography's quantitative revolution. Progress in Human Geography, vol.28, n.5.

(2001a) Retheorizing economic geography: from the quantitative revolution to "cultural turn". Annals of the Association of American Geographers, Vol. 91, No.3, pp.546-565

. (2001b) 'In the beginning was economic geography': a science studies approach to disciplinary history. Progress in Human Geography, 25, 4, 521-544.

BOMFIM, P. A. de A. (2007) A ostentação estatística (um projeto geopolítico para o território nacional: estado e planejamento no período pós-64). Tese de Doutorado. Programa de Pós-Graduação em Geografia. Faculdade de Filosofia, Letras e Ciências Humanas, USP, 377p.

BURTON, I. (1972) The quantitative revolution and theoretical geography. In: Davies, W.K.D. (ed) The conceptual revolution in geography. London: University of London Press. 
COLE J. P.; KING, C. A. M. (1966) Quantitative geography: techniques and theories in geography. London: John Wiley.

CORRÊA, R. L. (1991/1992) Entrevista com o professor Roberto Lobato Corrêa. Geosul, n.12/13, p. 23-42.

. (1980) Da "Nova Geografia” à "Geografia Nova”. Revista de Cultura Vozes,

ano 74, vol. LXXIV, n.4, pp. 253-60.

COSTA, W. M. da (1989) O estado e as políticas territoriais no Brasil. São Paulo: Edusp.

DREIFUSS, R. A. (1981) 1964: a conquista do Estado (ação política, poder e golpe de classe).

Petrópolis: Vozes.

FAISSOL, S. (1997) Cinqüenta anos de Geografia. Entrevista com o Professor Speridião Faissol (conduzida por Helion Povoa Neto e João Rua) GeoUerj, n.1, p.55-70.

. (1987) A geografia na década de 80; os velhos dilemas e as novas soluções. Revista Brasileira de Geografia, Rio de Janeiro, v. 49, n. 3, p. 7-37, jul./set.

. (Org.). (1978) Tendências atuais na geografia urbano/regional: teorização e quantificação. Rio de Janeiro: Fundação IBGE. 301p.

GEIGER, P. (1997) Notas autobiográficas e reflexões. Geosul, n.17, pp.124-150.

HARVEY, D. (2005) A produção capitalista do espaço. São Paulo: Annablume.

IANNI, O. (1971) Estado e planejamento econômico no Brasil. (1930-1970). Rio de Janeiro: Civilização Brasileira.

IBGE. (1967) Esboço preliminar da divisão do Brasil em espaços homogêneos e espaços polarizados. Rio de Janeiro: IBGE, CNG, Divisão de Geografia, sem numeração.

LATOUR, B. (2000) Ciência em ação: como seguir cientistas e engenheiros sociedade afora. SãoPaulo: Ed. UNESP.

(1999) Pandora's Hope: essays on the reality of science studies. Cambridge: Harvard University Press.

PEREIRA, L. C. B. (1985) Desenvolvimento e crise no Brasil 1930-1983. 14ª ed. São Paulo: Brasiliense. . (1981) A sociedade estatal e a tecnoburocracia. São Paulo: Brasiliense.

PENHA, E. A. A criação do IBGE no contexto da centralização política do Estado Novo. Rio de Janeiro: Fundação IBGE, 1993.

REIS JUNIOR, D. F. C. (2007) Cinquenta Chaves. O físico pelo viés sistêmico, o Humano nas mesmas vestes... e uma Ilustração Doméstica: O Molde (Neo) Positivista examinado em textos de Antonio Cristofoletti. Tese (Doutorado em Geografia) - Instituto de Geociências , Unicamp, 448p.

. (2003) O humano pelo viés quantitativo: um exame do (neo)positivismo em Speridião Faissol, através da leitura de textos selecionados. Rio Claro: Dissertação de Mestrado. Área de Concentração em Organização do Espaço. Instituto de Geociências e Ciências Exatas, UNESP, 141p.

ROSSI, P. (1992) Os sinais do tempo: história da Terra e história das nações de Hooke a Vico. Rio de Janeiro: Cia das Letras.

SMITH, N. (1989) Uneven development and location theory: toward a synthesis. IN: New models in geography. Edited by Richard Peet and Nigel Thrift. London: Unwin Hyman. 


\section{NOTAS}

1. A maior parte das leituras que fiz, foi concentrada, obviamente, nos geógrafos que aderiram a ou que criticaram a geografia quantitativa. Sendo assim, as impressões que revelo de tais recollections estão concentradas em leituras que cobrem a produção do IBGE do período de meados de 60 a início de 80, aproximadamente.

2. Tal empreendimento, que relaciona narrativas sobre a história política brasileira com a história institucional do IBGE, por conta das finalidades do presente texto, não será realizado, entretanto, cumpre apontar algumas importantes referências utilizadas na pesquisa que deu origem ao artigo: sobre a história do IBGE, destacam-se Almeida (1994 e 2000); Penha (1993); Bomfim (2007); Costa (1989). Sobre a história política do Brasil, especialmente nos anos do regime militar, destacam-se Dreifuss (1981); Ianni (1971); Pereira (1985, 1981).

3. Research Paper no. 111, Department of Geography, University of Chicago.

4. Esse fato, por exemplo, preponderava nos intercâmbios travados entre geógrafos do IBGE e instituições acadêmicas nos Estados Unidos e na França, desde 1940. Muita mais que afinidades teóricas, as escolhas se davam em função do domínio da língua.

5. Macedo Soares e Zarur compõem o que Almeida (2000) denominou de 'velha guarda' do IBGE. Cada um ao seu tempo teria chefiado o Conselho Nacional de Geografia, no período pós-Vargas. Criaram grupos de pesquisa, quase independentes e estabeleceram-se em posições antípodas espraiadas em questões relacionadas a política interna, a metodologias de pesquisa, a visões disciplinares. Merece comentário o fato de que em todos os depoimentos concedidos por ibgeanos que viveram intensamente as tensões e distensões das décadas de 40 e 50, é feita menção à contenda envolvendo o Macedo e Zarur. Além disso, é comum encontrar nesses textos momentos em que os autores revelam a que grupos pertenciam (Geiger, 1997; Corrêa, 1991/1992; Faissol, 1995 e 1997).

6. Segundo Geiger, no período desenvolvimentista, anterior ao regime militar, os geógrafos perderam espaço na administração pública, espaço que foi ocupado pelos economistas - sendo a criação da Fundação Getúlio Vargas, em 1944, um exemplo de tal fato. Essa situação iria alterar-se durante o regime militar, quando o IBGE se torna um importante braço do Ministério do Planejamento, competindo ao órgão a produção de estatísticas e estudos sobre a configuração espacial resultante dos processos de urbanização e industrialização que sofrera o país (Geiger, 1997, p.136).

7. Segundo Almeida (2000, p. 44) foram nos computadores de grande porte da PUC que rodaram as primeiras análises fatoriais e de agrupamentos necessárias para as pesquisas que foram iniciadas. O professor de sociologia da PUC Nelson do Vale Silva teria sido fundamental nessa ajuda operacional, tendo em vista o seu interesse em técnicas quantitativas para análise de dados sociais (Almeida, 2000, p. 92).

8. Cabe destaque ao fato de que esse impressionante acervo está disponível na página do IBGE na rede internacional de computadores, diga-se de passagem, com acesso gratuito, como deve ser.

9. Em 1978 foram publicadas duas edições; em 1979 foram publicadas duas edições; em 1984 foram publicados três números; em 1985 foram publicadas três edições; 1988 foram 6 números ao invés de 4, por conta da publicação de dois números especiais; em 1993, 1994, 1996 e 2005 foi publicada uma revista por todo o ano.

10. "Estudo das relações entre cidades e regiões". RBG, n.1, 1969.

11. "Regionalização". RBG, n.1, 1969.

12. “A experiência dos estudos de fluxos, no IBG, como subsídio à regionalização”. RBG, n.2, 1969.

13. $R B G, \mathrm{n} .4,1969$.

14. As teses a respeito dos pólos de desenvolvimento, desenvolvidas pelo economista francês François Perroux nos anos 50, foram bastante difundidas entre os economistas brasileiros, tendo 
sido absorvidas também pela geografia, especialmente nos trabalhos de regionalização (Bomfim, 2007, p. 178).

15. Não obstante a presença de Keller, estudiosa do tema de agrária, e que teve extensa produção no instituto.

16. $R B G$, n.1, 1970 .

17. Sobre Leo Waibel consultar Almeida (2000, pp. 121, 126-127).

18. "Tipos de agricultura no Paraná, uma análise fatorial”, RBG, n.4, 1970.

19. "Cidades do Nordeste. Aplicação do 'factor analysis' no estudo de cidades nordestinas". RBG, n. $4,1970$.

20. "Projeção da população no Brasil - aplicação do método cadeia de Markov". RBG, n.4, 1970.

21. RBG, n.1, 1972.

22. Cabe ressaltar que tal livro trata-se de uma coletânea de artigos organizada por Faissol. O livro é publicado pelo IBGE mas é resultado de um grupo de trabalho criado pela Comissão de Geografia do Instituto Pan-Americano de Geografia e História (IPGH). Faissol se faz bastante presente no livro, assina seis dos oito capítulos da obra (sendo que em três deles, Faissol é coautor junto aos integrantes do GAM e ex-estagiários. Este seria o grande livro texto que Faissol fez da geografia quantitativa. No primeiro capítulo Faissol volta a usar o mesmo título 'Teorização e Quantificação na Geografia' e, excetuando algumas inserções, trata-se do artigo de 1978, que será analisado a seguir.

23. $R B G, \mathrm{n} .4,1975$.

24. $R B G$, n.1, 1978.

25. É muito comum que essa tomada de rumo de Harvey, expressa na publicação de Social Justice and the City (1973) seja muitas vezes descrita, nos textos que se ocupam de seu pensamento, como uma deriva ou um desvio dos caminhos que antes trilhava quando escreveu Explanation in Geography (1969). Entretanto, o próprio Harvey não trata esse movimento como uma deriva ou desvio. Em entrevista concedida aos editores do periódico New Left Reviwew, republicada em A produção capitalista do espaço (2005), Harvey comenta que em Explanation já havia algum posicionamento seu em relação ao papel da geografia na sociedade, entendida naquele momento como sendo uma das ciências que forneceria importantes subsídios para um planejamento racional "quando a eficiência do planejamento regional e urbano seria uma ferramenta de melhoria social para toda a população" (Harvey, 2005, p. 19). Além disso, Harvey acredita que uma posição sua em relação à necessidade freqüente de um aprofundamento no plano teórico e epistemológico se manteve desde Explanation.

\section{RESUMOS}

Este artigo tem como objetivo analisar a produção da geografia quantitativa no Instituto Brasileiro de Geografia e Estatística (IBGE), durante o período de 1969 a 1978 a partir de pesquisa em artigos publicados na Revista Brasileira de Geografia, principal veículo de divulgação científica do Instituto.

This article aims to analyze the production of quantitative geography at the Brazilian Institute of Geography and Statistics (IBGE) from 1969 to 1978 by researching articles published by the Brazilian Journal of Geography (RBG), the institute's main vehicle of scientific communication. 
Este artículo tiene como objetivo analizar la producción de la geografía cuantitativa en el Instituto Brasileño de Geografía y Estadística (IBGE) en el período comprendido entre los años 1969-1978, a partir del análisis de los artículos publicados en la Revista Brasileña de Geografía (RBG), principal vehículo de comunicación científica del instituto.

Cet article analyse la production de la géographie quantitative à l'Institut Brésilien de Géographie et de Statistique (IBGE), pendant les années 1969-1978 à partir d'une recherche des articles publiés dans la Revue Brésilienne de Géographie (RBG), le principal véhicule de divulgation scientifique de l'Institut.

ÍNDICE

Índice geográfico: Brasil

Mots-clés: IBGE, géographie brésilienne, géographie quantitative

Palabras claves: IBGE, geografía brasileña, geografía cuantitativa

Palavras-chave: IBGE, geografia brasileira, geografia quantitativa

Índice cronológico: 1969-1978

\section{AUTOR}

\section{MARIANA LAMEGO}

Doutora em Geografia pela UFRJ; Professora do Centro Federal de Educação Tecnológica Celso Suckow da Fonseca (CEFET-Rio)

marilamego@gmail.com 